\title{
John Logie Baird and Television (Part 1)
}

By Adrian R. Hills

Spring 1996 Issue of KINEMA

EYE OF THE WORLD: JOHN LOGIE BAIRD AND TELEVISION (Part1)

1996 is the seventieth anniversary of the birth of television. John Logie Baird, the father of this pervasive technology, first publicly demonstrated television on 26 January 1926, in his small laboratory in the Soho district of London. Although large companies with great financial support were also working on the problem of television, Baird managed to surpass them all with very little money, a handful of unpaid helpers and equipment pieced together using rather unconventional materials. For example, Baird's choice of mechanical scanning as the most effective way of achieving true television required the use of spinning discs -- which of financial necessity were made of hatboxes and mounted on a coffin lid. This short account, written for the anniversary of the invention of television, not only recounts the events that led up to the first demonstration of television by John Logie Baird, but also describes some of the Scottish inventor's many areas of investigation.

John Logie Baird was born on 14 August 1888, the fourth child of Jessie and the Reverend John Baird. His family lived in a large house called "The Lodge" in Helensburgh, a coastal town which lies 25 miles northwest of Glasgow. By the turn of the century, this house had seen the development of a telephone exchange, had been supplied with electric lighting and had been the site of an early flight experiment, all of which were the work of the imaginative youngest child.

A telephone exchange was quite an achievement for a young schoolboy. Other children played with tin cans and pieces of string, but John Baird had tried this method and was dissatisfied. Instead, he made an electric exchange and connected his home to those of four of his friends. ${ }^{(1)}$ Unfortunately this telephone service was not in use for very long, as one of its low hanging wires caused the driver of a hansom cab to have an accident. This driver's protests soon led to the removal of the telephone wires from their various positions around the neighbourhood. Never one to waste resources, the boy then used the wires from his telephone exchange to set up a lighting system for The Lodge. Run by a petrol powered generator in the back garden, this activity made his parents' home the first in Helensburgh to have electric lighting.

John Logie Baird was also conducting experiments in other areas of research. The first year of this century saw the young inventor standing on the roof of his parents' house with a home-made glider. This experiment took place on a flat section of the roof of The Lodge, and had a rather strong impact on the rest of Baird's life. The glider was constructed with the assistance of his friend Godfrey Harris, but may not have been as well designed or constructed as some of his later machinery. Baird describes this incident in his autobiography Sermons, Soap and Television:

I had no intention of flying, but before I had time to give more than one shriek of alarm, Godfrey gave the machine one terrific push, and I was launched shrieking into the air. I had a few very nauseating seconds while the machine rocked wildly and then broke in half and deposited me with a terrific bump on the lawn. ${ }^{(2)}$

Fortunately, Baird was not seriously hurt by this fall, but elements of this particular experiment would surface again in his life. Just as he collaborated with young Godfrey Harris, he would always be ready to enlist the help of others. In later life, Baird's experiments would associate him with a diverse range of people, from a bright teen age radio enthusiast named Victor Mills to Winston Churchill's chief scientific advisor Frederick Lindemann. ${ }^{(3)}$

This glider incident gave Baird a great fear of flying, which would prevent him from travelling easily, and also foreshadowed the great difficulty he would have in maintaining his physical well-being. Even as a child, from the time he suffered an undiagnosed illness at the age of two, Baird's health was never good. Later on, as well as incurring various minor injuries in the early days of his work on television, he would also suffer from repeated physical breakdowns. After falling victim to a heart attack, Baird had time to write his 
autobiography while he was convalescing, but lived only another five years. He died on 14 June 1946, at a time when he was about to reinstate Britain as a world leader in television technology.

A healthy social life and an inventive nature seemed to be at variance with Baird's school career. The twelve year old boy is described in his school report as "very slow," "timid" and "...by no means a quick learner."(4) Nevertheless, Baird was not discouraged by his academic record, and in 1906 entered a diploma course in electrical engineering at the Glasgow and West of Scotland Technical College. ${ }^{(5)}$ He graduated from this course on 1 October 1914, and then entered Glasgow University to upgrade his diploma to a Bachelor of Science. ${ }^{(6)}$ Unfortunately, World War One broke out, and Baird never completed his degree. Baird, now 26 years old, tried on many occasions to enlist with the army, but was repeatedly rejected as unfit for army service. He therefore continued his various investigations, including work on television.

The earliest suggestion of Baird's interest in television technology is an experiment which he conducted at his parents' house in 1903. ${ }^{(7)}$ This experiment involved the attempted construction of a selenium photo-electric cell, but was unsuccessful, and Baird burnt his hands in the process. Although John Logie Baird suggests that he first started work on a complete television system in Hastings, there is evidence that he actually began ten years earlier. In 1976, Peter Waddell wrote an article which quoted sources suggesting that Baird first experimented with a complete television system between 1912 and 1915, while living in Yoker and working towards his electrical engineering diploma at the Glasgow College. ${ }^{(8)}$ R.W. Burns reinforces this suggestion in his 1986 book British Television: The Formative Years. ${ }^{(9)}$ In 1996, Malcolm Baird said that his father's work in Yoker can now be considered a definite possibility. ${ }^{(10)}$

The most fully substantiated evidence for Baird's early television work is found on the south coast of England, in Hastings in 1923. Even here, there is a certain amount of controversy, for Baird himself writes that he travelled directly from London to Hastings, where he then started work on television. This statement is untrue, for although Baird did travel to the south coast, it was not first to Hastings but to another seaside town called Folkestone. Since this new information has been released, a plaque has been placed on 26 Guildhall Street in Folkestone, in order to commemorate Baird's early television work there. According to R.W. Burns, Baird was definitely in Hastings during the winter of 1922 to $1923 .^{(11)}$ This situation therefore suggests that Baird was simultaneously renting accommodation in Folkestone and Hastings.

In order to tackle the problem of television, John Logie Baird chose a system which employed mechanical scanning. There were various methods available to achieve this, and Baird selected a system which used the Nipkow disc as being the most promising. Invented by Paul Nipkow in 1884, this disc had a series of apertures cut into it, which could then be used to scan an image. This disc was combined with other discs, and produced a very different television set from the ones we use today, for Baird's system did not use the cathode ray tube which is the most common method of displaying an image on modern television equipment.

Baird was quite capable of inventing his machines, but he was not quite so capable of their construction. For this reason, he enlisted the help of two young Hastings boys, Victor Mills and Norman Loxdale. Mills assisted Baird in the refinement of his electronics and Loxdale made various components, including a Nipkow disc with two spirals of apertures which were covered with orange-red and blue-green filters. Loxdale later described his surprise at Baird's experimentation with this disc, as at that time the inventor had not yet achieved a television picture. ${ }^{(12)}$ This surprise can be more easily understood when one realises that this disc was capable of producing colour and/or three dimensional pictures.

Other experiments conducted by Baird at this time involved the transmission, reflection and detection of radio waves which determined the distance of an object. According to Loxdale, Baird did some of these experiments in his laboratory at 8 Queen's Avenue in Hastings, and the inventor later conducted further experiments of a similar nature from a local hilltop. ${ }^{(13)}$ The significance of these tests is that they were very early examples of experimentation with a technology that was later to become famous during World War Two -- namely, radar. ${ }^{(14)}$

Although Baird was not accepted into military service at the beginning of World War One, there is evidence that he joined the military services. On 1 June 1976, a Mr. James Heath wrote a letter to Helensburgh library, stating that he saw Baird in 1928 or 1929, dressed as "...a Lieutenant in the Supplementary Reserve of Officers... [and he] was conducting experiments in several types of army field communications and new 


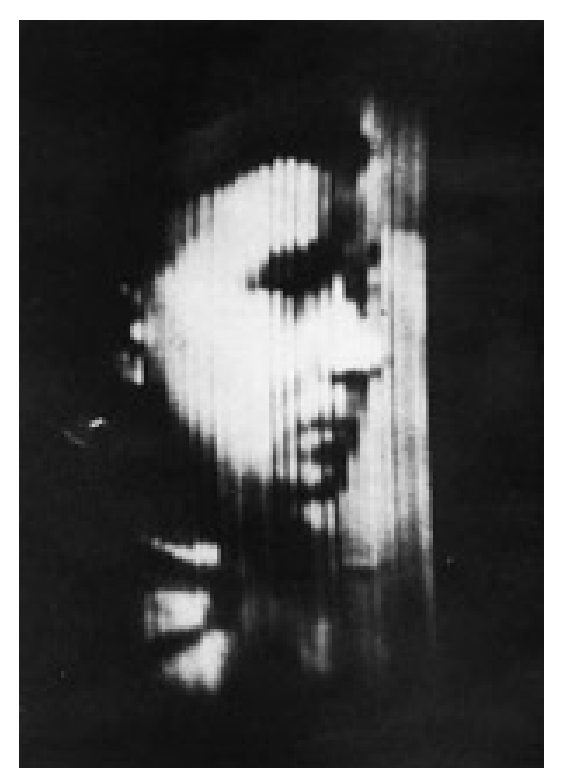

Figure 1: An image from J. L. Baird's Televisor

systems." Heath suggests that these new systems involved "...an invention to send pictures through the atmosphere." In other words, this statement implies that John Logie Baird was not only working on television for public use, but also for use in secret signalling for the armed forces.

Tom McArthur and Peter Waddell report the above information in their book The Secret Life of John Logie Baird, which was published in 1986. ${ }^{(15)}$ These authors have uncovered a remarkable amount of previously undisclosed work which connects John Logie Baird with radar and secret signalling, and more information will eventually be published by Peter Waddell and Douglas Brown on this subject.

There were two main problems which Baird would have to overcome in order to achieve television: the problem of the insensitivity of the photo-electric cell, and also the difficulty of obtaining a clear image. At first, he could only produce pictures of the outline of shapes, known as "shadowgraphs." C.F. Jenkins in America and D. von Mihaly in Hungary were also working on the problem of television, and had also produced shadowgraphs. However, Baird was able to solve his main difficulties and go beyond these two inventors in achieving true television.

To overcome his first problem, Baird worked with an assistant in Tunbridge Wells on the development of a photo-electric cell. The experimentation was successful, and he eventually produced a cell that "...was entirely different from existing cells on the market. ${ }^{(16)}$ The second problem was solved by Baird's refinement of his electronics. Douglas Brown suggests that Baird's system was as poor as everyone else's, but it was his use of a technique called "sharpening" that finally produced a television picture. ${ }^{(17)}$ Sharpening is an electronic method which brings a picture into focus in the same manner in which a normal lens focuses an image.

Almost eleven years to the day after graduating with an electrical engineering diploma from the Royal Technical College in Glasgow, John Logie Baird first achieved a recognisable television image. In his autobiography, Baird describes this historic occasion.

The image of the dummy's head formed itself on the screen with what appeared to be almost unbelievable clarity...I ran down the little flight of stairs to Mr. Cross' office, and seized by the arm his office boy William Taynton, hauled him upstairs and put him in front of the transmitter... ${ }^{(18)}$

After paying Taynton two shillings and sixpence to stay in position, Baird finally saw a human face recognisably reproduced on his apparatus. Baird waited four months, until 26 January 1926, before demonstrating his achievement to the Royal Institute and a reporter from The Times newspaper. 
John Logie Baird's achievement of television brought him great recognition. He went on to become a well known public figure in Great Britain. In 1931 married the concert pianist Margaret Albu. The couple had two children, Diana and Malcolm. Diana is a retired schoolteacher living near Glasgow, and Malcolm is a professor in chemical engineering at McMaster University in Hamilton, Ontario, Canada, as well as a Baird historian in his own right.

Baird's work did not stop with his achievement of true television. He went on to develop television for cinemas, both colour and three dimensional television, and also investigated further into secret signalling and radar technology. The fall edition of Kinema will contain a complementary article by Malcolm Baird, examining his father's work following the first demonstration of television.

The author wishes to acknowledge the editing assistance of Kristine Schmitt.

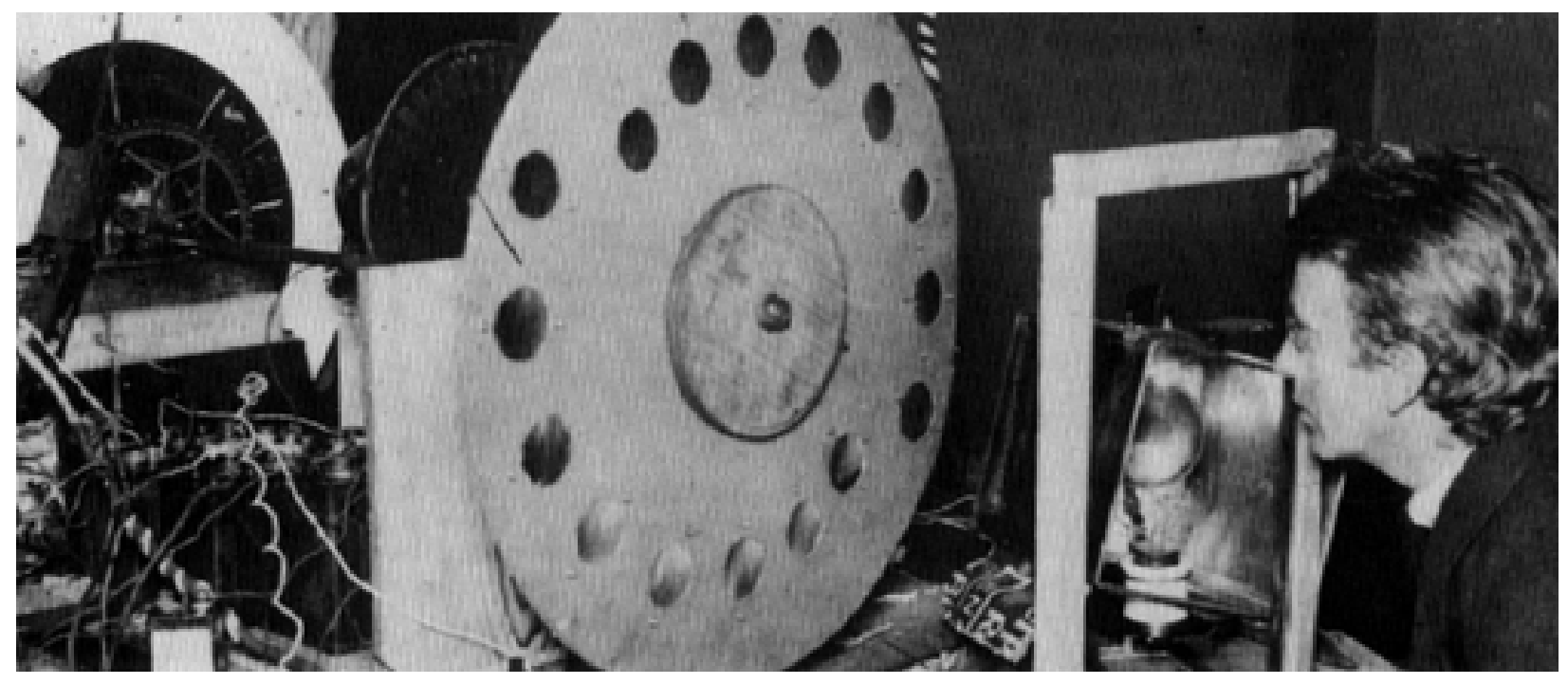

Figure 2: J. L. Baird and his television apparatus

\section{Notes}

1. The home-made, varnished wooden box that formed the centre of this telephone exchange still exists and is in the possession of Baird historian Neil Rimington of Eastbourne, England.

2. John Logie Baird, Sermons, Soap and Television (Croydon: Royal Television Society, 1990), p. 18.

3. Peter Waddell, personal interview, 20 December 1995. Waddell states that Professor Lindemann was associated with Baird from 1932 to 1939. This scientist was also involved in meetings with Baird, which discussed secret signalling. Lindemann applied for a patent on secret signalling on 6 April 1938.

4. Baird's school report, Larchfield School, Christmas 1900. 5. This academic institution is now called Strathclyde University, and is the location of ongoing research on John Logie Baird by Peter Waddell and Douglas Brown. 6. Baird's diploma from the Glasgow and West of Scotland Technical College, 1 October 1914.

7. Margaret Baird, Television Baird (Capetown: Haum 1973), p. 7.

8. Peter Waddell, "Seeing by Wireless", New Scientist, 11 November 1976. The two references are: The Motor News, 26 June 1926, 788 and William Imrie, Both Sides of the Burn: The Story of Yoker (Bell, Aird and Coghill, 1966).

9. R.W. Burns, British Television: The Formative Years (London: P. Peregrinus, 1986). Interestingly, this reference quotes a different source from Waddell's: A. Kempsell, "The man with many dreams", Helensburgh 
Times, 3 September 1975, p.15.

10. Malcolm Baird, personal interview, 28 February 1996.

11. R.W. Burns, British Television: The Formative Years, p. 8.

12. Thornton H. Bridgewater, interview with Norman Loxdale and Victor Mills, 8 April 1981.

13. Ibid. A plaque has been placed at 8 Queen's Avenue to commemorate Baird's television work.

14. By 26 October 1926, Baird had advanced his investigations so far that he felt confident enough to apply for British patent GB 292,185 on "...a reflected radio wave television system" Tom McArthur and Peter Waddell, Vision Warrior (Orkney: Orkney Press 1990), p. 227.

15. The second edition of this book, with added information, was published in 1990 under the title Vision Warrior. This book is available from Peter Waddell in the department of mechanical engineering, University of Strathclyde, Glasgow, Scotland.

16. R.W. Burns, British Television: The Formative Years, 52. This reference quotes a report on Baird's work which was written by Mr. E.G. Stewart in April 1926.

17. Douglas Brown, personal interview, 20 December 1995. Brown will be publishing the results of his investigations in this area of Baird's work under the title John Logie Baird and the Realisation of Television.

18. John Logie Baird, Sermons, Soap and Television, p. 57.

\section{Author Information}

Adrian R. HILLS was born in London, England. He graduated in film studies from the University of Waterloo, Ont., Canada and received his PhD degree in Glasgow, Scotland. His research involves early television and the pioneering work of John Logie Baird. 